\title{
Self-care of young people with long-term physical and mental health conditions
}

DOI:

10.7748/ncyp.2016.e761

\section{Document Version}

Accepted author manuscript

Link to publication record in Manchester Research Explorer

\section{Citation for published version (APA):}

Kirk, S., \& Pryjmachuk, S. (2016). Self-care of young people with long-term physical and mental health conditions. Nursing children and young people, 28(7), 20-28. https://doi.org/10.7748/ncyp.2016.e761

\section{Published in:}

Nursing children and young people

\section{Citing this paper}

Please note that where the full-text provided on Manchester Research Explorer is the Author Accepted Manuscript or Proof version this may differ from the final Published version. If citing, it is advised that you check and use the publisher's definitive version.

\section{General rights}

Copyright and moral rights for the publications made accessible in the Research Explorer are retained by the authors and/or other copyright owners and it is a condition of accessing publications that users recognise and abide by the legal requirements associated with these rights.

\section{Takedown policy}

If you believe that this document breaches copyright please refer to the University of Manchester's Takedown Procedures [http://man.ac.uk/04Y6Bo] or contact uml.scholarlycommunications@manchester.ac.uk providing relevant details, so we can investigate your claim.

\section{OPEN ACCESS}




\section{Supporting the Self-Care of Young People with Long-term Physical and Mental Health Conditions: Implications for Children's and Mental Health Nursing}

Susan Kirk PhD, MSc, BNurs, RN, RM, RHV, DN Cert.

Professor of Family and Child Health

School of Nursing, Midwifery and Social Work, University of Manchester

Steven Pryjmachuk BSc, PhD, MSc, PGDipEd, RN, CPsychol, SFHEA Professor of Mental Health Nursing Education

School of Nursing, Midwifery and Social Work, University of Manchester 


\begin{abstract}
Increasing numbers of children and young people experience long-term physical and mental ill health and how well they and their families manage their health and wellbeing is likely to influence their health in adulthood and their future life chances. This paper examines the evidence about 'what works' in supporting self-care in relation to children/young people with physical and mental health conditions. This is based on two systematic reviews and on research evaluating different selfsupport programmes that have been developed in the United Kingdom. We identify four key components of an effective and acceptable self-care programme that nurses can include when developing and providing such programmes for children and young people with long-term physical and mental health conditions. We also highlight the increasingly important role that children's and mental health nurses will play in supporting young people's self-care as a result of transformations in health care and nursing education.
\end{abstract}




\section{Introduction}

Increasing numbers of children and young people experience long-term physical and mental health problems. In relation to young people aged between 11 and 15 years old, 15\% experience long-term illness or disability and 10\% a mental health problem (Green et al 2005; Brooks et al 2011; Department of Health (DH)/NHS England 2015). Most of these young people are likely to face a lifetime of managing their health and wellbeing. How well they (and their families) do this is likely to influence their health in adulthood and their future life chances.

For a number of years self-care and self-management have been emphasised in health policy in the United Kingdom (UK) (DH, 2005, 2006, 2012a,b; NHS 2014). This has been in response to the increasing prevalence of long-term illness and the associated financial costs to health services as well the influence of consumerism and a public desire for personalisation and control over health (Wanless 2002, DH, 2005). Although the importance of self-care and self-management are referred to in child health policies they have not been given significant emphasis (DH/Department for Education and Skills 2004; DH, 2009, 2015).

The conceptualisation and implementation of self-care and self-management in policy and practice has not been without criticism. It has been noted that although framed in a patient-centred language they can be seen as a way of transferring costs and responsibilities onto patients and families (Coulter \& Ellins 2006; Morden et al. 2012). Indeed it has been suggested they resonate with an underlying policy imperative of individuals having a moral responsibility to look after their health and be empowered, 'activated' patients and 'good' citizens even though some will lack the skills, ability, resources or motivation to do this and may also face social and material barriers (Kendall et al 2011; Brooks et al 2015; Dwarswaard et al 2015; Foss et al 2015; Moore et al 2015). Furthermore it has been noted that professionals' understandings of self-care and self-management are based on a model of compliance rather than empowerment (Sawyer and Aroni 2005; Sadler et al. 2014; Dwarswaard et al 2015). A common criticism is that self-care and self-management tend to focus on the individual and changing their behaviour; neglecting not only their social context and lay understandings of long-term illness but also the influence and roles played by families and social networks (Rosland and Piette 2010; Audulv 2013; Ong et al 2014; Sadler et al 2014; Dwarswaard et al 2015; Miller et al 2015). This is particularly pertinent in relation to children/young people as parents play an important role in self-management/care and peers exert an influence over beliefs and behaviours. 


\section{Self-care and self-management}

Although the terms self-care and self-management are used interchangeably in the literature distinctions can be made between them. Self-care is generally used in relation to both health promotion and long-term condition management whereas self-management is associated more with the latter (Kirk et al 2010). Indeed it could be argued that self-management is a sub-category of selfcare. A body of research has examined what influences self-care/self-management and identified self-care/self-management activities and their underpinning behaviours (Figures 1 and 2). In mental health research and practice the terms 'self-care' and 'self-management' have been used less frequently although 'recovery' (Gillard et al 2010; Brooks, Davidson) and 'self-help' (Pryjmachuk et al. 2014) can be seen as analogous approaches. Recovery similarly emphasises positive health and wellbeing, social networks, empowerment, partnership working and encourages a focus on strengths, positive coping and resilience (Gillard et al. 2010; Leamy et al 2011; Le Boutillier et al 2011).

In this paper we will use the term 'self-care' and we will examine the evidence about 'what works' in supporting self-care in relation to children/young people with physical and mental health conditions. This will be based on two studies that we have conducted that involved systematic reviews and empirical research (Kendal et al 2016; Kirk and Milnes, 2015; Kirk et al. 2010; 2012, 2013; Pryjmachuk et al. 2014). In this paper we summarise and synthesise the findings from these studies.

\section{Self-care support}

The aim of self-care support is to enable individuals to enhance their health in relation to three areas: medical management of their condition, carrying out usual roles and activities and managing the emotional impact of their condition (Lorig \& Holman 2003). Although self-care support can be thought of as being part of 'routine' professional practice, it is often associated with particular programmes or interventions which may be facilitated by health care professionals, lay workers or peers. These programmes usually aim to develop individuals' confidence, knowledge and skills using a range of cognitive-behavioural strategies and information resources (Barlow et al 2002; Boger et al 2015). Skills developed include problem-solving and decision-making skills and skills to help individuals effectively use resources and communicate with professionals.

Self-care support can be provided in a range of different ways (e.g. information provision, skills training, support networks, professional education) and via a variety of platforms (e.g. devices and technologies, real and virtual networks) (Department of Health, 2005). They can be group or 
individual-based; focus on particular conditions or be generic. They may be provided by the NHS or other organisations in the public, private and third sectors and may be lay-led (e.g. virtual/online support groups and networks). In relation to childhood long-term physical and mental health conditions a range of different interventions for children/young people and parents have been developed and evaluated by researchers (Kirk et al 2013).

\section{What works? Evidence from Systematic Reviews}

Our two systematic reviews evaluated self-care support interventions for children and young people with long-term physical and mental health conditions (Kirk et al. 2010, 2013; Pryjmachuk et al. 2014). They looked at the available international evidence from quantitative and qualitative studies with the aim of identifying what was effective in improving outcomes and their acceptability to children/young people, parents and health care professionals.

Details on the individual self-care interventions evaluated in the reviews are presented in Kirk et al. $(2010,2013)$ and Pryjmachuk et al. (2014). Interventions varied in relation to their:

- Theoretical basis (e.g. self regulation theory, social learning theory)

- Aims

- Target (children/young people only, parents only, children/young people and parents; family including siblings; professionals)

- Location (home/community, hospital, school, combination of locations)

- Leadership/facilitation (lay or professional)

- Mode of delivery (e.g. face-to-face, virtual, individual child/family, group-based)

- Focus (condition-specific or generic)

Our reviews found that there is evidence that self-care interventions can improve a range of outcomes (Kirk et al. 2010, 2013; Pryjmachuk et al. 2014). They can improve children's health in relation to areas such as lung function, glycaemic control and mental health symptoms (e.g. anxiety, depression) (Barrett et a 2004; Jan et al. 2007; Biegel et al 2009; Wade et al. 2009). Interventions may also enhance self-efficacy, self-esteem, knowledge/skills and quality of life though there is less evidence of this for children with mental health conditions (Pfiffner et al 1997; Cicutto et al. 2005; Franklin et al. 2006; Biegel et al 2009; Dobson et al 2010). The evidence for whether these 
interventions reduce health service use is mixed with studies reporting both significant reductions and no reductions (Wesseldine et al. 1999; Flores et al. 2009).

Our review of interventions for children with mental health conditions found that interventions that focus on individual children/families are more effective than group-based interventions (Pryjmachuk et al. 2014). For physical health conditions group-based interventions were far more common and were found to improve health status and psychosocial wellbeing (Cicutto et al. 2005; Wade et al. 2009). Studies examining participants' views report that children/young people and parents value group-based approaches (either virtual or face-to-face) for providing social support and the opportunity to share experiences, information and strategies (Bruzzese et al. 2004; Trollvik and Servinsson, 2005; Garcia et al 2010; Garrawy et al 2010).

Some interventions investigated used e-health methods for self-care support, for example, computer games, online support groups, mobile phone text messaging. In the review focusing on long-term physical health conditions these were associated with improvements in psycho-social wellbeing, health status and condition-related knowledge (Christian and D'Auria 2006; Franklin et al. 2006; Jan et al. 2007). It also appears from both reviews that these types of interventions are acceptable to young people/parents as they are accessible and have the ability to 'fit into' daily life (Carroll et al. 2007; Van der Meer et al. 2007; Coyle et al 2009).

In relation to interventions for children/young people with mental health conditions it appeared that those delivered by generic professionals (e.g. general nurses, teachers) were as effective as those delivered by specialists (e.g. mental health nurses, clinical psychologists) (Pryjmachuk et al. 2014). This may relate to the use of manuals to promote standardisation in delivery or because it is the personal attributes and interpersonal skills of the professional rather than specialist training that is important. In both reviews the relationship with the facilitator and their interpersonal skills was seen as being important by children/young people and parents (Anderson, 1997; Trollvik and Severinnson 2005; Garcia et al 2010; Gowers et al 2010;). In the review of mental health interventions it appeared that greater contact time with the facilitator could be beneficial (Pryjmachuk et al. 2014). This could be because this provided more opportunity to develop a therapeutic alliance. 


\section{What Works: Evidence from Empirical Research}

We conducted case studies of different types of self-care support programmes operating in the United Kingdom to identify their acceptability and effectiveness from the perspectives of children/young people, parents and the professionals/workers involved in their delivery. Information about the programmes we studied and the research participants are provided in Tables 1 and 2 .

The two studies identified similar key components of effective and acceptable programmes. These were providing a sense of community, developing knowledge and skills, building independence and confidence and engaging children/young people (Figure 3) (Kirk et al. 2010; 2012; Pryjmachuk et al. 2014).

Figure 3: Key Components of Self-care Support

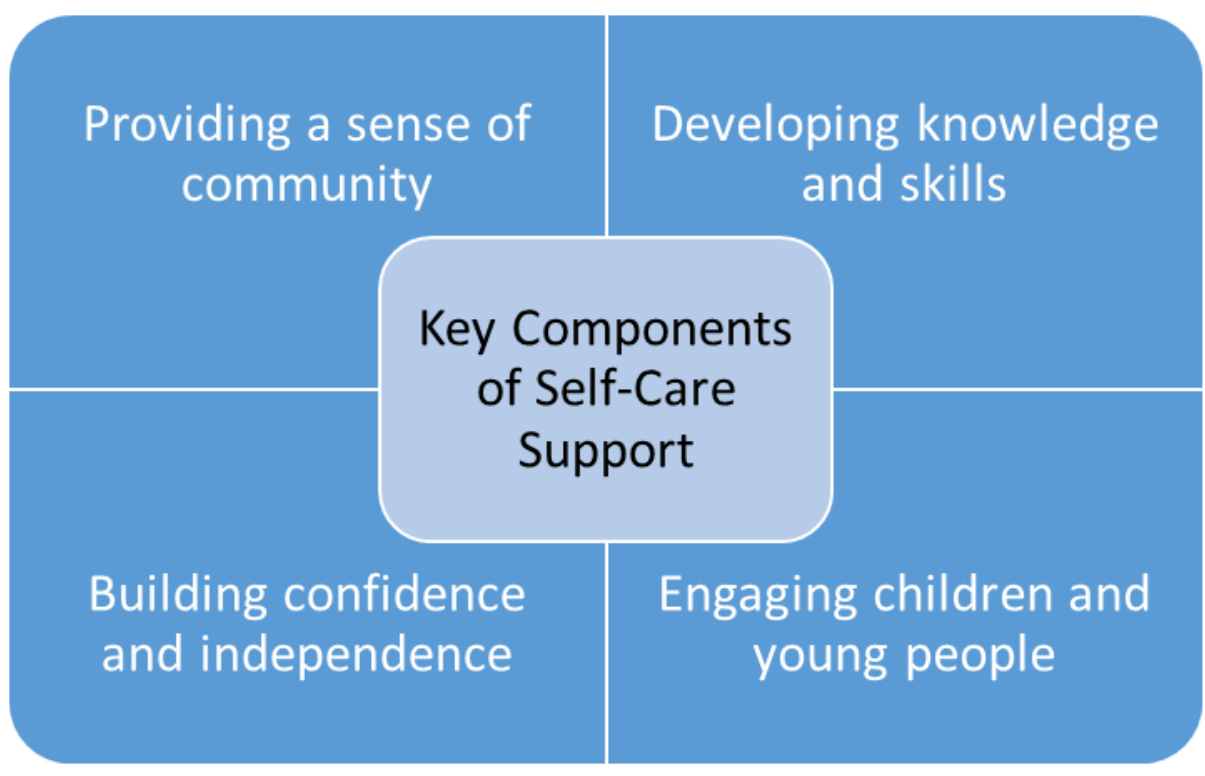

Providing a sense of community was seen as an important component for three reasons. Firstly, it enabled the exchange of knowledge, skills and information. Participants described how they benefitted from the sharing of experiential knowledge gained from living with the condition and selfcare techniques that others had found helpful. Secondly peer support reduced a sense of isolation and feelings of difference. Before participating in the self-care support programme parents and 
young people had often felt alone. Accessing the programme resulted in the realisation that there were others experiencing similar feelings and issues and the group was seen as a safe place where feelings could be expressed, shared and understood. Thirdly programmes had the potential to extend social networks. In some cases friendships developed through participation in the programme. However, some participants felt a sense of loss if these friendships ended when the programme finished. Some mental health programmes discouraged socialisation outside peer group meetings due to fears that uncontrolled peer support might trigger self-harm behaviours or problems with eating (Pryjmachuk et al. 2014; Kendal et al 2016). Participants noted that the acceptability of peer support depended on the individual and their preferences and readiness for this form of support.

Participants described the important role of programmes in developing their knowledge and understanding of their or their child's condition. This knowledge was acquired through formally provided sessions and as highlighted earlier from the sharing of experiential knowledge. This included knowledge of the condition itself, how it affected themselves or their child and the development of self-care skills. The latter often included practising skills in their everyday lives outside the programme setting. Some programmes also helped develop young people's communication skills to enable them to communicate more confidently and effectively with health care professionals and teachers.

Building young people's independence and self-confidence was seen as important component of self-care programmes directed at children/young people with physical health conditions. This was less explicit in the self-care support programmes directed at children/young people with mental health conditions though reducing dependence, improving self-esteem, increasing resilience were implied, if not explicit, aims of the programmes evaluated. Programmes could include activities to help children/young people manage their condition independently but in a supportive environment. Such activities could also increase parent's confidence in transferring self-care responsibilities to their children and thus increase their independence. For programmes focussing on physical health conditions, providing opportunities for children/young people to participate in challenging activities (e.g. abseiling) was seen as building their self-esteem and demonstrating to their parents their capabilities and appropriate limitation boundaries. In addition, peer support and feedback could enhance feelings of self-confidence. 
The ability of programmes to engage children/young people was seen as a key component. Fundamentally programmes needed to be accessible and provided in an attractive physical environment appropriate to the target group. It was emphasised that any activities aimed at promoting self-care had to be perceived by children/young people as enjoyable as well as gender and age appropriate. Being 'young person friendly' encompassed using children's/young people's ways of communicating such as text messaging and online methods (Kirk and Milnes, 2015; Kendal et al 2016). The inter-personal skills of workers involved in the programmes was highlighted as being vital and the personal qualities emphasised were approachability, being non-judgemental, active listening, empathy, compassion and trustworthiness. In relation to mental health programmes giving children/young people individual time and attention appeared to be a valued characteristic.

\section{Conclusions}

We found substantial similarities between physical health and mental health self-care support programmes in relation to impact on outcomes and in terms of children/young people's and parents' views of these programmes. One difference that emerged was that programmes focussing on individual children or families may be more effective in improving mental health outcomes although children/young people with mental health problems still valued peer support. Other systematic reviews have similarly reported that self-management interventions for children/young people, including those using the internet, can improve a range of health outcomes (Stinson et al. 2009; Lindsay et al 2014).

It is important to note that the research included in our systematic reviews varied in terms of its quality. Many studies lacked a theoretical basis and clearly defined and robustly measured outcomes. Some studies used parents as proxies despite evidence that parents and children can assess outcomes differently (Upton et al. 2005; Palermo et al. 2008). Outcomes relating to psychosocial well-being, condition-related knowledge and health behaviour were less frequently measured, particularly in mental health studies, even though self-care support interventions are essentially psycho-educational in nature and these types of outcomes are likely to be valued by families. In general there has been a focus on trials with limited high quality research on children/young people's or parents' views about self-care support interventions. Moreover, children, young people and parents have often not been involved in intervention development or in identifying outcomes of importance to them. It is also often unclear whether interventions have been adapted for different age groups or whether cultural diversity has been taken into account. 
Many interventions have an individual behaviour change focus although researchers are now beginning to consider using more comprehensive theories to build interventions such as socioecological theory and social network theory (Miller et al. 2015). In addition it was evident, particularly in the mental health review, that researchers had frequently tried to ensure consistency in intervention delivery usually by using manualised approaches. Whilst this is important in a research setting, it emphasises fidelity over acceptability thus neglecting the individuality of children, young people and families in terms of their needs, preferences, experiences and resources. Our reviews suggest that computer-based interventions are both effective and acceptable. The use of the internet and mobile technology for self-care support has increased rapidly in recent years due to its potential for providing low cost support without geographical and temporal barriers (Silva et al 2015). However, concerns have been raised about quality, safety and integration with wider health services (Hussain et al 2015).

Our empirical work identified a range of approaches that have been implemented in practice and we have examined their acceptability and effectiveness from the perspectives of children/young people, parents and the professionals/workers involved in their delivery. Whilst the findings cannot be generalised in a quantitative sense, the combined sample sizes (145 participants) are large for a study of this nature and are drawn from a range of different self-care support approaches. We acknowledge that the sample only includes participants who chose to access these services. Four key components of self-care programmes emerged from this research: providing a sense of community, promoting independence and confidence, developing knowledge and skills and engaging children/young people. These components are supported by the evidence from the systematic reviews, particularly in relation to physical health conditions (Table 3 ) and provide an underpinning framework for self-care programme development.

The majority of the self-care support interventions included in our reviews do not appear to have been subsequently implemented in clinical practice. In some cases this may be due to the interventions being too resource intensive to be feasible to provide in the health service or this may relate to well-recognised and long-standing barriers to translating research into practice (Squires et al 2011). Nevertheless self-care is an important area for nursing practice and one where nurses should play a leadership role. 


\section{Implications for Children's and Mental Health Nurses}

Our research suggests that there are four key components to an effective and acceptable self-care programme; providing a sense of community, promoting independence and confidence, developing knowledge and skills and engaging children/young people. Knowledge of these key components can be used by nurses and researchers in the development and delivery of self-care support programmes for children and young people with long-term physical and mental health conditions.

There are significant opportunities for nurses to support self-care in children and young people, not just in routine clinical practice but also in its promotion and in the potential to collaborate with others involved in its delivery. In our studies, many of the self-care support programmes were delivered by third sector organisations or by non-health professionals (such as teachers and youth workers) with little or no linkage to health services or health professionals. Nurses working with children and young people would benefit from broadening their networks to ensure that they are engaging and working with all professionals and non-professionals (and this includes children and young people and their parents and caregivers) who have a stake in promoting and supporting the physical and mental health of children and young people.

In terms of the direct delivery of care for children and young people with physical and mental health conditions, there are opportunities for nurses to integrate self-care support into routine clinical care and to include self-care support programmes in care pathways. Doing so should increase the uptake and availability of these programmes.

More fundamentally, the values, attitudes, knowledge and skills necessary to support self-care need to be incorporated within professional practice and pre-qualifying education programmes. The Department of Health's (2008) core principles for supporting self-care provide a useful framework for developing practice and education (Figure 4). According to this framework, nurses need to have the skills and knowledge to be able to: communicate effectively; identify people's strengths and abilities; provide advice on support networks; promote choice and independence; enable people to manage identified risks; and provide relevant and evidence-based information.

Finally, nurses need to understand that the UK, like much of the developed world, is facing a future where health service utilisation will be dominated by those with long-term physical and mental health conditions (NHS England, 2014). In this context, providing support for self-care and selfmanagement is intrinsic to government plans for transforming future health care, not only because of the significant cost savings but also because self-care approaches embrace empowerment and 
partnership. Nurses are ideally placed to be at the forefront of these transformations; indeed, nurses enabling healthy lives and supporting children/young people and their families to self-care is one of the cornerstones of the proposed changes to registered nurse education and training advocated in Lord Willis' Shape of Caring review (Health Education England, 2015).

\section{Acknowledgements}

We would like to acknowledge the contribution of our research teams in the research reported in this paper: Linda Milnes, Sarah Kendal, Peter Bower, Peter Callery, Susan Beatty, Rebecca Elvey, Roger Catchpole. We would also like to thank the research participants for sharing their experiences, the self-care projects for participating in the study and for providing valuable help with recruitment, and the study advisory groups for their insight and guidance.

The projects were funded by the National Institute for Health Service and Delivery Research (HS\&DR) programme. The views and opinions expressed therein are those of the authors and do not necessarily reflect those of the NIHR HS\&DR programme or the Department of Health. 


\section{References}

Anderson, J. (1997). An Evaluation of an Adolescent Diabetes Education Program Canadian Journal of Diabetes Care 21 28-33

Audulv, A (2013) The over time development of chronic illness self-management patterns: a longitudinal qualitative study. BMC Public Health 13:452.

Barlow, J; Wright,C; Sheasby,J; Turner, A. (2002) Self-management approaches for people with chronic conditions: a review. Patient Education and Counselling. 48, 177-87

Barrett PM, Lock S, Farrell LJ. (2005) Developmental differences in universal preventive intervention for child anxiety. Clinical Child Psychology and Psychiatry 10:539-55.

Biegel GM, Brown KW, Shapiro SL, Schubert CM. (2009) Mindfulness-based stress reduction for the treatment of adolescent psychiatric outpatients: A randomized clinical trial. Journal of Consulting Clinical Psychology 77:855-66.

Brooks, F, Magnusson, J, Klemera, E, Spencer, N \& Morgan, A. (2011) HBSC England National Report: Health Behaviour in School-aged Children (HBSC): World Health Organization Collaborative Cross National Study. University of Hertfordshire.

Brooks, H; Rogers, A; Sanders, C; Pilgrim, D. (2015) Perceptions of recovery and prognosis from longterm conditions: The relevance of hope and imagined futures Chronic Illness 11(1) 3-20

Boger E, Ellis J, Latter S, Foster C, Kennedy A, Jones F, et al. (2015) Self-Management and SelfManagement Support Outcomes: A Systematic Review and Mixed Research Synthesis of Stakeholder Views. PLoS ONE 10(7): e0130990. doi:10.1371/journal.pone.0130990

Bower, P., Blakeman, T., Kennedy, A., Protheroe, J., Richardson, G., Rogers, A. \& Sanders, C. (2009) What Influences People to Self-Care? National Primary Care Research and Development Centre, University of Manchester, Manchester, UK.

Bruzzese, JM; Bonner, S; Vincent, E; Sheares, B; Mellins, RB; Levison, MJ; Wieseman, S; Du, Y; Zimmerman, BJ and Evans, D. (2004). Asthma Education: The Adolescent Experience. Patient Education and Counselling. 55, 396-406

Carroll, A. E., Marrero, D. G. \& Downs, S. M. (2007) The HealthPia ${ }^{\mathrm{TM}}$ GlucoPack Diabetes phone: a usability study. Diabetes Technology \& Therapeutics, 9, 158-164.

Christian, B. J. and D'Auria, JP. (2006). Building life skills for children with cystic fibrosis: effectiveness of an intervention. Nursing Research. 55(5): 300-7.

Cicutto, L; Murphy, S; Coutts, D; O’Rourke, J; Lang, G; Chapman, C. et al. (2005). Evaluating an asthma center's efforts to provide education to children with asthma in schools. Chest. 128: 19281935

Coulter, A and Ellins, J. (2006) Patient-focused interventions: A review of the evidence London: The Health Foundation. 
Coyle D, Doherty G, Sharry J. (2009) An evaluation of a solution focused computer game in adolescent interventions. Clinical Child Psychology and Psychiatry 14:345-60

Davidson, L. (2005) Recovery, self-management and the expert patient - Changing the culture of mental health from a UK perspective, Journal of Mental Health, 14:1, 25-35

Department of Health (2005) Self Care - A Real Choice: Self Care Support - A Practical Option. The Stationery Office, London, UK.

Department of Health (2006) Supporting People with Long Term Conditions to Self Care: A Guide to Developing Local Strategies and Good Practice. London: Department of Health.

Department of Health (2008) Core Principles to Support Self-Care. London: Department of Health.

Department of Health (2009) Healthy Lives, Brighter Futures. London: Department of Health.

Department of Health (2012) The Mandate: A mandate from the Government to the NHS Commissioning Board: April 2013 to March 2015 London: Department of Health

Department of Health (2012) Long Term Conditions Compendium of Information (Third Edition). London: Department of Health

Department of Health (2015) Report of The Children and Young People's Health Outcomes Forum 2014/15. London: Department of Health

Department of Health, Department for Education and Skills (2004) National Service Framework for Children, Young People and Maternity Services: Children and Young People Who Are III. Department of Health, London, UK

Department of Health /NHS England (2015) Future in mind Promoting, protecting and improving our children and young people's mental health and wellbeing. London: Department of Health

Dobson KS, Ahnberg Hopkins J, Fata L, Scherrer M, Allan LC. (2010) The prevention of depression and anxiety in a sample of high-risk adolescents: a randomized controlled trial. Canadian Journal of School Psychology 25:291-310.

Dwarswaard, J; Bakker, EJM; van Staa, A; Boeije, HR (2015) Self-management support from the perspective of patients with a chronic condition: a thematic synthesis of qualitative studies. Health Expectations. Early View doi: 10.1111/hex.12346

Flores, G., Briddon, C., Torres, S., Perez, R., Walter, T., Brotanek, J., Lin, H. \& Tomany-Korman, S. (2009) Improving asthma outcomes in minority children: a randomised, controlled trial of parent mentors. Pediatrics, 124, 1522-1532

Franklin, V. L., Waller, A., Pagliari, C. \& Greene, S. A. (2006) A randomized controlled trial of Sweet Talk, a text-messaging system to support young people with diabetes. Diabetic Medicine, 23, 1332-1338.

Foss, C; Knutsen, I; Kennedy, A; Todorova, E; Wensing, M; Lionis, C; Portillo, MC; Serrano-Gil, M; Koetsenruijter, J; Mujika, A; Rogers, A. (2015). Connectivity, contest and the ties of self-management 
support for type 2 diabetes: a meta-synthesis of qualitative literature. Health \& Social Care in the Community. Early view doi: 10.1111/hsc.12272

Garcia C, Pintor JK, Lindgren S. (2010) Feasibility and acceptability of a school-based coping intervention for Latina adolescents. Journal of School Nursing 26:42-52

Garraway H, Pistrang N. (2010) 'Brother from another mother': mentoring for African-Caribbean adolescent boys. Journal of Adolescence 33:719-29

Gillard S, Edwards C, White S, White R, Adams K, Davies L. (2010) The Barriers and Facilitators of Supporting Self Care in Mental Health NHS Trusts. Southampton: National Institute for Health Research Service Delivery and Organisation Programme.

Gowers SG, Clark AF, Roberts C, Byford S, Barrett B, Griffiths A, et al. (2010) A randomised controlled multicentre trial of treatments for adolescent anorexia nervosa including assessment of cost-effectiveness and patient acceptability - the TOuCAN trial. Health Technology Assessment. 14(15).

Green H, McGinnity A, Meltzer H, Ford T, Goodman R (2005). Mental health of children and young people in Great Britain, 2004. A survey carried out by the Office for National Statistics on behalf of the Department of Health and the Scottish Executive. Basingstoke: Palgrave Macmillan

Grey, M; Schulman-Green, D; Knafl, K; Reynolds,N (2015) A revised Self- and Family Management Framework Nursing Outlook 63 162-170

Health Education England (2015) Raising the Bar Shape of Caring: A Review of the Future Education and Training of Registered Nurses and Care Assistants. (Willis Report). Health Education England, Leeds.

Hussain, M; Al-Haiqi, M; Zaidan, A.A; Zaidan, BB; Kiah, M; Anuar, NB; Abdulnabi, M (2015) The landscape of research on smartphone medical apps: Coherent taxonomy, motivations, open challenges and recommendations. Computer Method and Programs in Biomedicine 122: 393-408

Jan, RL; Wang, JY; Huang, MC; Tseng, MS; Su,HJ; Liu,LF. (2007). An Internet-Based Interactive Telemonitoring System for Improving Childhood Asthma Outcomes in Taiwan. Telemedicine and Ehealth. 13 (3) 257-68.

Kendal,S; Kirk, S; Elvey, R; Catchpole, R; Pryjmachuk, S. (2016) How a moderated online discussion forum facilitates support for young people with eating disorder. Health Expectations. Online early view. view doi: 10.1111/hex.12439

Kendall, E; Ehrlich, C; Sunderland, N; Muenchberger, H; Rushton, C. (2011) Self-managing versus selfmanagement: reinvigorating the socio-political dimensions of self-management. Chronic Illness 7 , 87-98

Kirk, S. and Milnes, L. (2015) An Exploration of How Young People and Parents Use Online Support in the Context of Living with Cystic Fibrosis. Health Expectations. (Early View) doi: 10.1111/hex.12352

Kirk, S; Beatty, S; Callery, P; Milnes, L; Pryjmachuk, S. (2010) Evaluating self-care support for children and young people with long-term conditions. Southampton, National Institute for Health Research Service Delivery and Organisation Programme. 
Kirk, S; Beatty, S; Callery, P; Milnes, L. Pryjmachuk, S. (2012) Perceptions of Effective Self-Care Support for Children and Young People with Long-term Conditions. Journal of Clinical Nursing 21 (1314) $1974-1987$

Kirk, S; Beatty, S; Callery, P; Gellatly, J; Milnes, L. Pryjmachuk, S. (2013) The Effectiveness of Self-Care Support Interventions for Children and Young People with Long-term Conditions: A Systematic Review. Child: Care, Health and Development. 39 (3) 305-324.

Leamy, M; Bird, V; Le Boutillier, C; Williams, J; Slade, M (2011) Conceptual framework for personal recovery in mental health: systematic review and narrative synthesis British Journal of Psychiatry 199:445-452.

Le Boutillier,C; Leamy, M; Bird, V; Davidson, L; Williams, J; Slade, M (2011) What Does Recovery Mean in Practice? A Qualitative Analysis of International Recovery-Oriented Practice Guidance Psychiatric Services 62 (12) 1470-76

Lindsay, S; Kingsnorth, S; McDougall, C.; Keating, H (2014) A systematic review of self-management interventions for children and youth with physical disabilities. Disability and Rehabilitation 36(4): 276-288

Lorig, K., Ritter, P., Stewart, A., Sobel, D., Brown, B., Bandura, A.,.Holman, H. (2001). Chronic disease self-management program. 2-year health status and health care utilization outcomes. Medical Care, 39(11), 1217 e1223.

Lorig, K.R. and Holman, H. (2003) Self-management education: history, definition, outcomes, and mechanisms. Annals of Behavioral Medicine 26 (1): 1-7

Miller, WR; Lasiter, S; Bartlett Ellis, R; Buelow, JM. (2015) Chronic disease self-management: A hybrid concept analysis. Nursing Outlook. 63 154-61

Moore, L; Frost, J; Britten, N. (2015) Context and complexity: the meaning of self-management for older adults with heart disease. Sociology of Health \& IIIness 37 (8) 1254-1269,

Morden AW, Jinks C, Ong BN. (2012). Rethinking 'risk' and self-management for chronic illness. Social Theory and Health, vol. 1(10), 78-99

NHS England (2014) Five Year Forward View. NHS England, Redditch

Ong BN, Rogers A, Kennedy A, Bower P, Sanders T, Morden A, Cheraghi-Sohi S, Richardson JC, Stevenson F. (2014). Behaviour change and social blinkers? The role of sociology in trials of selfmanagement behaviour in chronic conditions. Sociology of Health \& IIIness, vol. 36(2), 226-238

Palermo, T. M., Long, A. C., Lewandowski, L., Drota, D., Quittner, A. L. \& Walker, L. S. (2008) Evidence-based assessment of health-related quality of life and functional impairment in pediatric psychology. Journal of Pediatric Psychology, 33, 983-996

Pfiffner L, McBurnett K. (1997) Social skills training with parent generalization: treatment effects for children with attention deficit disorder Journal of Consulting Clinical Psychology 65: 749-57. 
Pryjmachuk S, Elvey R, Kirk S, Kendal S, Bower P, Catchpole R. (2014). Developing a model of mental health self-care support for children and young people through an integrated evaluation of available types of provision involving systematic review, meta-analysis and case study. Health Services and Delivery Research, 2(18) DOI:10.3310/hsdr02180

Rosland, AM and Piette, JD (2010) Emerging models for mobilizing family support for chronic disease management: a structured review. Chronic Illness 6: 7-21

Sadler, E; Wolfe, CD; McKevitt, C. (2014) Lay and health care professional understandings of selfmanagement: A systematic review and narrative synthesis SAGE Open Medicine 2:

2050312114544493

Sawyer, SM and Aroni, RA (2005) Self-management in adolescents with chronic illness. What does it mean and how can it be achieved? Medical Journal of Australia 183 (8) 405-09

Silva, BM; Rodrigues, JP; Torre Díez, I; López-Coronado, M; Saleem, K (2015) Mobile-health: A review of current state in 2015 Journal of Biomedical Informatics 56 265-272

Squires, JS; Hutchinson, AM; Boström, AM; O'Rourke, H; Cobban, SJ; Estabrooks, C (2011) To what extent do nurses use research in clinical practice? A systematic review. Implementation Science 6 $: 21$

Stinson, J; Wilson, R; Gill, N; Yamada, J; Holt, J. (2009) A Systematic Review of Internet-based SelfManagement Interventions for Youth with Health Conditions. Journal of Pediatric Psychology 34(5) 495-510.

Trollvik, A and Severinsson, E. (2005). Influence of an Asthma Education Program on Parents with Children Suffering from Asthma. Nursing and Health Sciences. 7, 157-163.

Upton, P., Eiser, C., Cheung, I., Hutchings, H. A., Jenney, M., Maddocks, A., Russell, I. T. \& Williams, J. G. (2005) Measurement properties of the UK-English version of the Pediatric Quality of Life Inventory 4.0 (PedsQL) generic core scales. Health and Quality of Life Outcomes, 3, 22.

Van der Meer, V; van Stel, H; Detmer, SB; Otten, W; Sterk, P and Sont, JK (2007). Internet-Based SelfManagement Offers an Opportunity to Achieve Better Asthma Control in Adolescence Chest 132 (1) 112-119.

Wade, T. A., Watson, M. D., Gillespie, C., Thomas, N., Filuk, S., McColm, J., Piwniuk, M. \& Becker, A. (2009) Small group, interactive education and the effect on asthma control by children and their families. Canadian Medical Association Journal, 181, 257-263.

Wanless, D. (2002) Securing Our Future Health: Taking A Long-Term View (Final Report). HM Treasury, London, UK.

Wesseldine, L; McCarthy, P; Silverman, M. (1999). Structured discharge procedure for children admitted to hospital with acute asthma: a randomised controlled trial of nursing practice. Archives of Disease in Childhood. 80: 110-14. 
Figure 1: Influences on Self-Care/Self-Management (Bower et al 2009; Grey et al 2015)

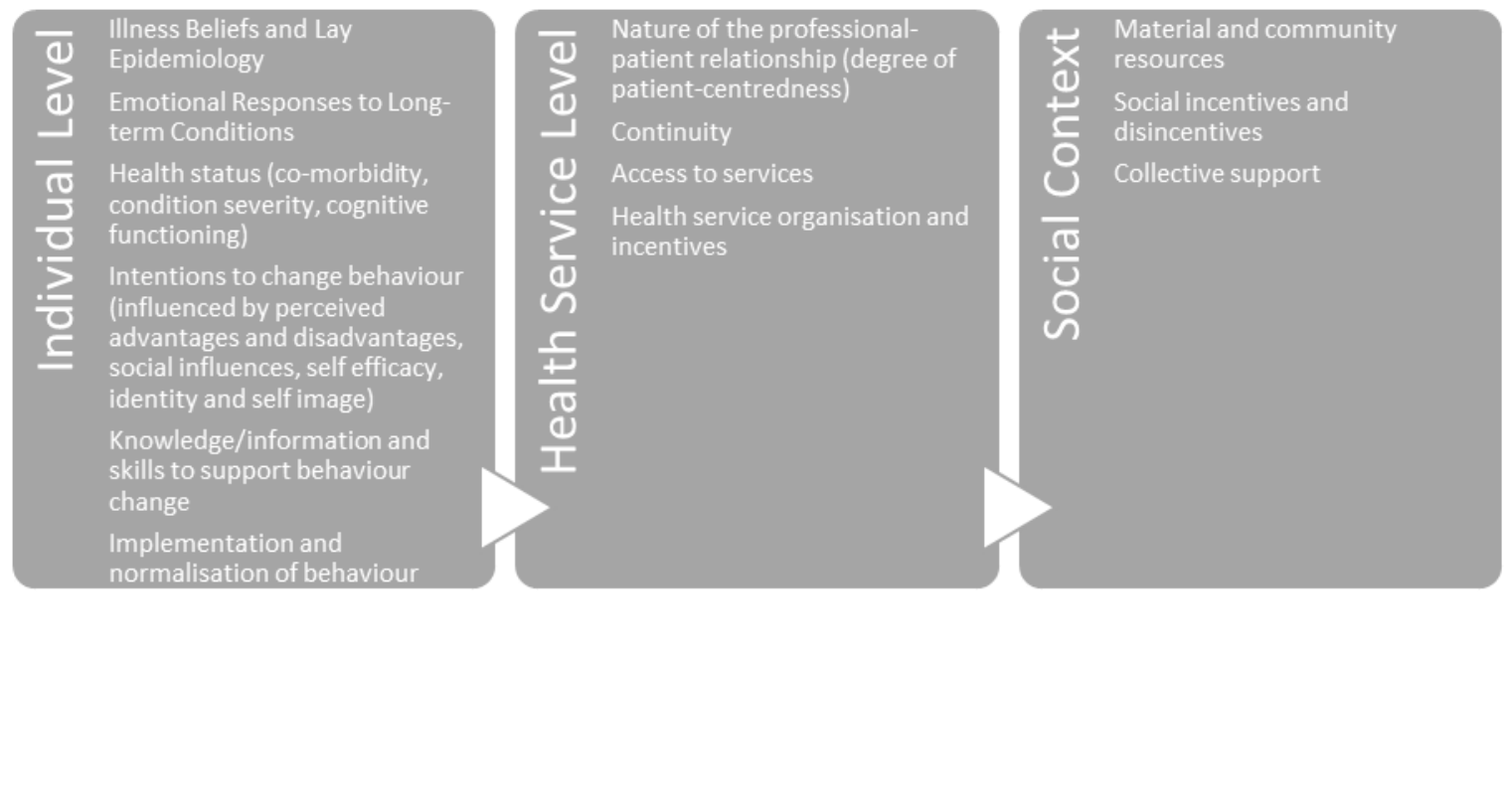


Figure 2: Self-Care and Self-Management Activities and Behaviours (Lorig et al 2001,2003)

\section{Self-Care/ Self-Management}

Activities

-Maintaining and enhancing mental and physical wellbeing

-Managing symptoms and treatments

- Self-diagnosis

- Self-monitoring

-Managing the emotional impact of the

condition (e.g. managing emotions and

identity; socio-cultural consequences of

condition; lifestyle changes)

-Managing consequences of illness on

daily/family life (e.g. carrying out everyday roles/activities)

-Information seeking

-Developing supportive networks

- Seeking advice/support from social

networks

- Navigating health and other services

- Consulting professionals and services

-Developing partnerships with professionals
Core Self-Care/Self-Management Behaviours

-Problem solving

-Decision making

-Resource utilization

- Forming relationships

- Taking action.

- Self-tailoring (individualising) 
Table 1: Key Characteristics of the Self-care Support Programmes ( $n=12)$

\begin{tabular}{|c|c|c|c|c|c|c|c|c|c|c|c|c|}
\hline Characteristics & $\begin{array}{l}\text { Residential } \\
\text { camps }\end{array}$ & ADHD Group & $\begin{array}{c}\text { Structured self- } \\
\text { management } \\
\text { programme }\end{array}$ & $\begin{array}{c}\text { Online support } \\
\text { group }\end{array}$ & Diabetes Team & Support Team & $\begin{array}{c}\text { Self-harm } \\
\text { Psycho-therapy } \\
\text { Group } \\
\end{array}$ & $\begin{array}{c}\text { Dina School } \\
\text { (Incredible } \\
\text { Years) }\end{array}$ & $\begin{array}{l}\text { Parenting } \\
\text { Programme }\end{array}$ & $\begin{array}{c}\text { Resilience } \\
\text { Focussed } \\
\text { Family Support }\end{array}$ & $\begin{array}{c}\text { Online support } \\
\text { group }\end{array}$ & $\begin{array}{l}\text { Supported } \\
\text { online CBT }\end{array}$ \\
\hline $\begin{array}{l}\text { Theoretical or } \\
\text { philosophical } \\
\text { basis }\end{array}$ & $\begin{array}{l}\text { Self-efficacy } \\
\text { Social support }\end{array}$ & $\begin{array}{l}\text { Empowerment } \\
\text { Self-efficacy }\end{array}$ & $\begin{array}{l}\text { Self-efficacy } \\
\text { Empowerment }\end{array}$ & Social support & None identified & None identified & $\begin{array}{l}\text { Group } \\
\text { psychotherapy, } \\
\text { CBT, DBT. }\end{array}$ & $\begin{array}{l}\text { Social Learning } \\
\text { Theory }\end{array}$ & $\begin{array}{l}\text { Social } \\
\text { Learning } \\
\text { Theory } \\
\end{array}$ & $\begin{array}{l}\text { Resilience, } \\
\text { solution focus }\end{array}$ & Recovery & CBT \\
\hline Target & CYP aged 6-17) & $\begin{array}{l}\text { CYP aged 5-18 } \\
\text { Parents/carers } \\
\text { Professionals }\end{array}$ & $\begin{array}{l}\text { Young people } \\
\text { aged } 12-18\end{array}$ & $\begin{array}{l}\text { CYP } \\
\text { Parents } \\
\text { (separate } \\
\text { groups) } \\
\end{array}$ & $\begin{array}{l}\text { CYP up to } \\
\text { 18years } \\
\text { Parents }\end{array}$ & $\begin{array}{l}\text { CYP up to } 18 \\
\text { years } \\
\text { Parents }\end{array}$ & $\begin{array}{l}\text { YP aged 14-17; } \\
\text { parents }\end{array}$ & $\begin{array}{l}\text { Children aged } \\
5-6 \text { years }\end{array}$ & $\begin{array}{l}\text { Parents of } \\
\text { children aged } \\
2-4 \text { years }\end{array}$ & $\begin{array}{l}\text { C/YP (5-14 } \\
\text { years); } \\
\text { Parents }\end{array}$ & $\begin{array}{l}\text { YP up to } 25 \\
\text { years }\end{array}$ & $\begin{array}{l}\text { YP 14-30 } \\
\text { years }\end{array}$ \\
\hline Location & $\begin{array}{l}\text { Community } \\
\text { National } \\
\text { coverage }\end{array}$ & $\begin{array}{l}\text { Community } \\
\text { Local area } \\
\text { coverage }\end{array}$ & $\begin{array}{l}\text { Community } \\
\text { National coverage }\end{array}$ & $\begin{array}{l}\text { Home } \\
\text { National } \\
\text { coverage }\end{array}$ & $\begin{array}{l}\text { Hospital } \\
\text { Home } \\
\text { Community } \\
\text { Local area } \\
\text { coverage }\end{array}$ & $\begin{array}{l}\text { Home } \\
\text { Community } \\
\text { Local area } \\
\text { coverage }\end{array}$ & $\begin{array}{l}\text { Hospital } \\
\text { Local area } \\
\text { coverage }\end{array}$ & $\begin{array}{l}\text { School } \\
\text { Local area } \\
\text { coverage }\end{array}$ & $\begin{array}{l}\text { Community } \\
\text { Local area } \\
\text { coverage }\end{array}$ & 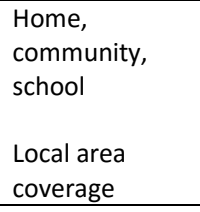 & $\begin{array}{l}\text { Online } \\
\text { National } \\
\text { coverage }\end{array}$ & $\begin{array}{l}\text { Community } \\
\text { Local area } \\
\text { coverage }\end{array}$ \\
\hline Leadership & $\begin{array}{l}\text { Third sector } \\
\text { Lay volunteers } \\
\text { and HCPs } \\
\text { One paid } \\
\text { manager per } \\
\text { camp }\end{array}$ & $\begin{array}{l}\text { Third sector. } \\
\text { Lay volunteers } \\
\text { and paid workers. }\end{array}$ & $\begin{array}{l}\text { Third sector } \\
\text { Lay facilitators } \\
\text { aged } 15-25\end{array}$ & $\begin{array}{l}\text { Third sector. } \\
\text { Moderation } \\
\text { only. }\end{array}$ & $\begin{array}{l}\text { NHS } \\
\text { Professionals } \\
\text { Some parent } \\
\text { volunteers. }\end{array}$ & $\begin{array}{l}\text { NHS } \\
\text { Professionals } \\
\text { (Clinical Nurse } \\
\text { Specialists, } \\
\text { general nurses } \\
\text { and a Social } \\
\text { Worker) }\end{array}$ & NHS & $\begin{array}{l}\text { Local authority } \\
\text { and NHS }\end{array}$ & Third sector & Third sector & Third sector & Third sector \\
\hline Focus & Asthma & ADHD & Generic & $\mathrm{CF}$ & Diabetes & Generic & Self-harm & $\begin{array}{l}\text { Emerging } \\
\text { behaviour or } \\
\text { emotional } \\
\text { problems } \\
\end{array}$ & $\begin{array}{l}\text { Behaviour } \\
\text { problems }\end{array}$ & $\begin{array}{l}\text { Behaviour } \\
\text { problems }\end{array}$ & Eating disorder & $\begin{array}{l}\text { Depression } \\
\text { and anxiety }\end{array}$ \\
\hline Medium & $\begin{array}{l}\text { Face-to-face in } \\
\text { a holiday } \\
\text { location }\end{array}$ & $\begin{array}{l}\text { Face-to-face } \\
\text { groups } \\
\text { (discussion, } \\
\text { activities) in } \\
\text { community } \\
\text { centre. Separate } \\
\text { groups for } \\
\text { parents and } \\
\text { children, activity } \\
\text { programme for } \\
\text { YPs. }\end{array}$ & $\begin{array}{l}\text { Face-to-face } \\
\text { groups } \\
\text { (discussion, } \\
\text { activities) in non- } \\
\text { NHS locations. }\end{array}$ & $\begin{array}{l}\text { Online peer } \\
\text { support via } \\
\text { discussion } \\
\text { groups }\end{array}$ & $\begin{array}{l}\text { Face-to-face } \\
\text { groups } \\
\text { (discussion, } \\
\text { activities) in } \\
\text { community and } \\
\text { hospital } \\
\text { settings; } \\
\text { residential } \\
\text { holidays }\end{array}$ & $\begin{array}{l}\text { Face-to-face } \\
\text { home based } \\
\text { support and } \\
\text { telephone } \\
\text { advice for } \\
\text { individual } \\
\text { families; trips } \\
\text { for children and } \\
\text { siblings. }\end{array}$ & $\begin{array}{l}\text { Face-to-face } \\
\text { groups }\end{array}$ & $\begin{array}{l}\text { Face-to-face } \\
\text { groups }\end{array}$ & $\begin{array}{l}\text { Face-to-face } \\
\text { groups }\end{array}$ & $\begin{array}{l}\text { Face-to-face } \\
\text { individual } \\
\text { support }\end{array}$ & $\begin{array}{l}\text { Online peer } \\
\text { support via } \\
\text { discussion } \\
\text { groups }\end{array}$ & $\begin{array}{l}\text { Face-to-face } \\
\text { individual } \\
\text { support and } \\
\text { guided online } \\
\text { CBT. }\end{array}$ \\
\hline
\end{tabular}


Table 2: Sample Characteristics $(n=145)$

\begin{tabular}{|l|c|c|}
\hline Participant Group & Number & Percentage \\
\hline Children and Young People $^{1}$ & 43 & 29.7 \\
\hline Parents $^{2}$ & 47 & 32.4 \\
\hline Professionals/workers & 55 & 37.9 \\
\hline
\end{tabular}

${ }^{1}$ Aged 5 to 18 years; 25 male, 18 female

239 mothers, 8 fathers

Table 3: Relationships Between Key Components of Self-care Support and Systematic Review Evidence

\begin{tabular}{|c|c|}
\hline Key Component of Self-Care Support & Evidence from Systematic Reviews \\
\hline Providing a sense of community & $\begin{array}{l}\text { Group-based interventions - improve health status, } \\
\text { psychosocial wellbeing. } \\
\text { Mental health conditions - interventions that focus on } \\
\text { individual children/families are more effective than } \\
\text { group-based interventions in reducing symptoms. } \\
\text { Group-based approaches (either virtual or face-to- } \\
\text { face) valued for providing social support and the } \\
\text { opportunity to share experiences, information and } \\
\text { strategies }\end{array}$ \\
\hline Promoting independence and confidence & Self-care interventions can improve self-efficacy \\
\hline Developing knowledge and skills & $\begin{array}{l}\text { Self-care interventions can improve condition-related } \\
\text { knowledge }\end{array}$ \\
\hline Engaging children/young people & $\begin{array}{l}\text { Ehealth methods for self-care support (computer } \\
\text { games, online support groups, mobile phone text } \\
\text { messaging) can improve psycho-social wellbeing, } \\
\text { health status and condition-related knowledge. They } \\
\text { are seen acceptable delivery methods due to } \\
\text { accessibility and ability to 'fit into' daily life. } \\
\text { Relationship with facilitator and their interpersonal } \\
\text { skills are important for children, young people and } \\
\text { parents. } \\
\text { Greater contact time with facilitator can lead to } \\
\text { improved outcomes for children/young people with } \\
\text { mental health conditions. }\end{array}$ \\
\hline
\end{tabular}


Figure 4: Core Principles for Nursing in Supporting Self-Care (adapted from DH Core Principles to Support Self-Care, 2008)

\section{Ensure individuals are able to make informed choices to manage their self-care needs.}

- Practice is informed by the principles of respect, dignity, choice and independence for individuals.

- Nurses encourage and support individuals to make decisions

- Practice is based on values that support and empower individuals to be in control of their needs

Communicate effectively to enable individuals to assess their needs, and develop and gain confidence to self-care

-Nurses use communication and relationship skills to encourage and support individuals to work with them in identifying strengths and abilities; areas for development and to find solutions building on existing skills.

Support and enable individuals to access appropriate information to manage their self-care needs

-Nurses encourage and support individuals in accessing appropriate information and where possible provides the relevant and evidence based information in an appropriate manner, providing sufficient choice/options.

Support and enable individuals to develop skills in self-care

-Nurses facilitate access to appropriate training and self-care skills development within or outside their organisation in order to develop and support individuals' confidence and competence to self-care.

-The nurse also supports individuals in developing self-care skills Support and enable individuals to use technology to support self-care

-Nurses ensure appropriate equipment, tools and devices are discussed and where appropriate provided

- Nurses engage with individuals to support and enable the use of technology

Advise individuals how to access support networks and participate in the planning, development and evaluation of services

- Nurses advise individuals about participation in support networks both to receive from and give support to others

- Nurses promote and encourage involvement of individuals in the planning, development and evaluation of services they receive. Support and enable risk management and risk taking to maximise independence and choice

- Nurses encourage and support individuals to make choices about how to live their lives and manage any identified risks.

-Nurses promote choice and independence while supporting individuals to manage risks proportionately and realistically. 